\title{
ALPHA-CHYMOTRYPSIN*
}

\section{EXPERIMENTAL EVALUATION IN THE TREATMENT OF VITREOUS HAEMORRHAGES}

BY

\author{
S. D. PAUL AND O. P. AHUJA
}

From the Muslim University, Institute of Ophthalmology (Director: Prof. B. R. Shukla) and the Gandhi Eye Hospital, Aligarh, India

THE medical treatment of vitreous haemorrhage is as varied and complex as it is disappointing. Antitubercular antibiotics, tuberculin desensitization, calcium, corticosteroids, and radiotherapy have all been advocated at one time or another.

In recent years, such proteolytic enzymes as trypsin, hyaluronidase, streptokinase, and thrombolysin have been used in various inflammatory, oedematous, and vascular conditions of the ocular tissues, and conflicting reports of their efficacy have appeared.

Linn and Ozment (1950) reported that an intra-ocular injection of hyaluronidase did not clear the blood from the eye but produced local irritation.

Friedman (1952) and O'Rourke (1955) tried streptokinase in the treatment of hyphaema with poor results, but Hopen and Campagna (1955) and Schenk and Trichtel (1957) found trypsin effective in the resolution of post-operative hyphaema.

Boyer, Suran, Hogan, and McEwen (1958) and Chandler and Rosenthal (1958) obtained poor results with these enzymes in the treatment of vitreous haemorrhages.

Lijó Pavía (1959) used retrobulbar injections of alpha-chymotrypsin in the treatment of intra-ocular haemorrhage; he first gave 500 units and later increased the dose to 800 or 1,000 units at weekly intervals. He reported good results in twelve of fourteen cases.

Scheie, Ashley, and Weiner (1961) irrigated the anterior chamber of two patients suffering from total hyphaema with thrombolysin and obtained lysis with no serious damage to the ocular tissues.

The biochemical and pharmacological properties of alpha-chymotrypsin have been elaborately discussed by Schwartz and Schwartz (1960) who showed that the enzyme hydrolyses peptides at various points. The specificity of these sites distinguished this enzyme, although it can also hydrolyse other bonds such as esters and amides. The optimum $\mathrm{pH}$ for its action is between 7 and 9. Calcium stabilizes and enhances its action.

* Received for publication December 27, 1962. 
Organic phosphates such as diisopropyl-fluoro-phosphonate and substituted fatty acids such as chloramphenicol inhibit its action. They described it as less toxic than trypsin but able to produce allergic reactions, haemorrhagic pathological changes, prolonged coagulation time, and hypotension in larger doses.

Thorson and Leinfelder (1959) found no pathological change in the ocular tissues after placing alpha-chymotrypsin in the anterior chamber of rabbits and observing them for 9 weeks, but Radnót and Pajor (1961) reported that it produced marked changes in rabbit corneae.

Barraquer (1958) first showed that alpha-chymotrypsin exerted a strong proteolytic action on the zonular fibres.

Salmony (1959) demonstrated that alpha-chymotrypsin was capable of digesting ox vitreous, and Sekiguchi (1960) reported that an intravitreal injection of as little as $0.02 \mathrm{mg}$. alpha-chymotrypsin caused more or less severe changes in all the ocular tissues, damage to the retina being particularly serious.

Maumenee (1960) observed that an intravitreal injection of $0 \cdot 1 \mathrm{ml}$. of a 1:5,000 dilution of alpha-chymotrypsin produced changes varying from breakdown of the supporting fibres to almost complete atrophy of the retina.

O'Malley, Moskovitz, and Straatsma (1961) reported that an intravitreal injection of $0 \cdot 4 \mathrm{ml}$. 1:5,000 solution of alpha-chymotrypsin into the eye of a living dog produced vitreous inflammation and destructive retinal lesions.

Münich (1961) observed that alpha-chymotrypsin had a proteolytic action on the structural proteins of the human body, the effect being more marked in higher concentrations $(1: 5,000)$ and less marked in younger persons.

On the contrary, Edwards and Locke (1961) reported that the addition of $0.5 \mathrm{mg}$. alpha-chymotrypsin in $0.2 \mathrm{ml}$. distilled water to four samples of stored vitreous had no appreciable effect on its viscosity.

Fleming and Riddel (1961) reported that no antigenic response to the enzyme was detected in experimental animals.

\section{Present Investigations}

$0.25 \mathrm{ml}$. rabbit whole blood was injected into the vitreous body of the right eye in 35 adult albino rabbits (mean weight $4 \mathrm{lb}$.) through a posterior sclerotomy incision, thus simulating a vitreous haemorrhage. An attempt was made to keep the volume of the vitreous body almost constant by letting out an equivalent amount of vitreous through a separate posterior sclerotomy in the opposite segment.

The animals were then divided into seven groups of five each, according to the mode of administration of alpha-chymotrypsin which was carried out 24 hours later.

The presence of blood in the vitreous and the state of the fundus in each eye was then observed and recorded daily for up to 5 weeks with the help of a 
direct ophthalmoscope and slit lamp. The results of these observations and the type and amount of the injections in each group are all shown in the Table.

TABLE

ADMINISTRATION OF A.C.T. AND RESULTS IN SEVEN GROUPS

\begin{tabular}{|c|c|c|c|c|c|c|c|c|c|c|c|c|c|}
\hline \multirow{3}{*}{$\begin{array}{c}\text { Group } \\
\text { No. }\end{array}$} & \multicolumn{3}{|c|}{ Injection } & \multicolumn{9}{|c|}{ Results } & \multirow{3}{*}{ Tota } \\
\hline & \multirow[t]{2}{*}{ Route } & \multirow[t]{2}{*}{ Solution } & \multirow{2}{*}{$\underset{(\mathrm{ml} .)}{\operatorname{Amount}}$} & \multicolumn{4}{|c|}{$\begin{array}{l}\text { Blood Present in } \\
\text { Vitreous } \\
\text { (No. of Days) }\end{array}$} & \multicolumn{5}{|c|}{$\begin{array}{l}\text { Endophthalmitis } \\
\text { (Day of Appearance) }\end{array}$} & \\
\hline & & & & 7 & 8 & 9 & 10 & 1 & 2 & 3 & 4 & & \\
\hline I & \multicolumn{3}{|c|}{ Controls } & & 1 & 3 & 1 & & & & & & 5 \\
\hline II & Intravitreal & $1: 5,000$ & 0.25 & & & 1 & 1 & 1 & & 1 & & & 5 \\
\hline III & Retrobulbar & $1: 1,000$ & 0.5 & 2 & 2 & 1 & & & & & & & 5 \\
\hline IV & Subconjunctival & $1: 1,000$ & 0.5 & 3 & 2 & & & & & & & & 5 \\
\hline $\mathrm{V}$ & Intramuscular & $1: 1,000$ & 1.0 & & & 1 & & & & & & & 5 \\
\hline VI & Intravenous & $1: 1,000$ & 1.0 & & 2 & 3 & & & & & & & 5 \\
\hline VII & Intra-arterial & $1: 1,000$ & $1 \cdot 0$ & 1 & 1 & & & & 1 & & & & 5 \\
\hline
\end{tabular}

Histological Examination.-Fibrous tissue formation was seen on the retina and extending into the vitreous, together with a few patches of localized retinal atrophy in some eyes from all the various groups. Marked retinal atrophy was seen in Group II, which had had an intravitreal injection of alpha-chymotrypsin.

\section{Discussion}

The average interval between the injection and the disappearance of the blood from the vitreous varied little (from 7.5 to 8.5 days). It is evident, therefore, that alpha-chymotrypsin however administered did not influence the rate of absorption of blood. These results are similar to those obtained with other proteolytic enzymes by Friedman (1952), O'Rourke (1955), Schenk and Trichtel (1957), Chandler and Rosenthal (1958), and Boyer and others (1958).

Lijó Pavía (1959), however, reported encouraging results in cases of intra-ocular haemorrhage of various types, but gave no comparative data from a control group.

Endophthalmitis developed in three out of five eyes which received an intravitreal injection of alpha-chymotrypsin, in four eyes of Group V, and in three eyes of Group VII. Hence no conclusion could be reached regarding the ability of the enzyme to cause an allergic reaction as suggested by Schwartz and Schwartz (1960). 
Histological studies revealed that intravitreal injection of alpha-chymotrypsin may cause considerable damage to important intra-ocular structures. In Group II the retina was found to be grossly damaged. This finding conforms with those of Sekiguchi (1960), Maumenee (1961), and O'Malley and others (1961), but this property of the enzyme was not mentioned by Lijó Pavía (1959).

\section{Summary}

Alpha-chymotrypsin was administered after experimentally produced vitreous haemorrhages in rabbit eyes. The drug was given by injection by six different routes: subconjunctival, retrobulbar, intravitreal, intravenous, intramuscular, and intra-arterial.

Alpha-chymotrypsin did not hasten the absorption of vitreous haemorrhage in this investigation, and the intravitreal administration of alpha-chymotrypsin had toxic effects.

\section{REFERENCES}

Barraquer, J. (1958). Acta ophthal. (Kbh.), 36, 803.

Boyer, H. K., Suran, A. A., Hogan, M. J., and McEwen, W. K. (1958). A.M.A. Arch. Ophthal., 59, 333.

Chandler, M. R., and Rosenthal, E. (1958). Ibid., 59, 706.

EDWARDS, G. K., and LOCKE, J. C. (1961). Amer. J. Ophthal., 52, 37.

Fleming, T. C., and RIDDEL, G. H. (1961). Ibid., 51, 1104.

FRIEDMAN, M. W. (1952). Ibid., 35, 1184.

Hopen, J. M., and Campagna, F. N. (1955). Ibid., 40, 209.

Luó Pavía, J. J. (1959). Rev. oto-neuro-oftal. (B. Aires), 34, 68

LINN, J. G., and OzMENT, T. L. (1950). Amer. J. Ophthal., 33, 33.

Maumenee, A. E. (1960). Trans. Amer. Acad. Ophthal. Otolaryng., 64, 33.

MüNICH, W. (1961). v. Graefes Arch. Ophthal., 163, 88.

O'Malley, C., Moskovitz, M., and StraAtsma, B. R. (1961). Arch. Ophthal., 66, 539.

O'Rourke, J. F. (1955). Amer. J. Ophthal., 39, no. 2, pt 2, p. 119.

RADNót, M., and PAJOR, R. (1961). Ibid., 51, 598.

SAlMONY, D. (1959). Brit. J. Ophthal., 43, 321

Scheie, H. G., Ashley, B. J., and WeIner, A. (1961). Arch. Ophthal., 66, 226.

SCHENK, H., and Trichtel, F. (1957). Ophthalmologica (Basel), 134, 396.

Schwartz, B., and Schwartz, J. B. (1960). Trans. Amer. Acad. Ophthal. Otolaryng., 64, 17.

SEKIGUCHI, K. (1960). Jap. J. Ophthal., 4, 104.

Thorson, J. C., and LeINFElder, P. J. (1959). Midwest Section of the Association for Research in Ophthalmology, Inc., Denver, Colorado. 